\section{Field-Scale Runoff of Pesticides from Up- land Fields under Natural Rainfall}

\author{
Yoshiyuki TAKAHASHI, ${ }^{*}$ Masashi TAKATA, ${ }^{\dagger}$ \\ Yoshitsugu ODANAKA, ${ }^{+\dagger}$ Yoshifumi IzONO, ${ }^{+\dagger}+$ \\ Hiroyuki NAGAOKA, ${ }^{\dagger+\dagger}$ Kyota NumATA ${ }^{\dagger+\dagger}$ \\ and Toshikazu FuJITA ${ }^{\dagger}$ \\ Research Institute of Japan Plant Protection Association, 535 \\ Kessoku-cho, Ushiku, Ibaraki 300-1212, Japan \\ ${ }^{\dagger}$ Japan Plant Protection Association, 1-43-11 Komagome, \\ Toshima-ku, Tokyo 170-8484, Japan \\ ${ }^{+\dagger}$ Institute of Environmental Toxicology, Mitsukaido Institute, \\ 4321 Uchimoriya-cho, Mitsukaido, Ibaraki 303-0043, Japan

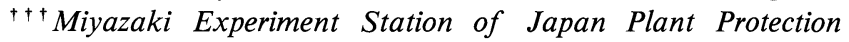 \\ Association, 11913 Sadohara-cho, Miyazaki-gun, Miyazaki \\ 880-0212, Japan
}

(Received March 22, 2002; Accepted May 27, 2002)

Key words: runoff, Gray lowland soil, Ando soil, pesticide residue on the soils.

\section{INTRODUCTION}

The occurrence of water runoff from croplands has raised concern over contamination by pesticides of public water sources. ${ }^{1)} \quad$ Thus, experiments with artificial and natural rainfall have been performed to investigate field-scale runoff., ${ }^{2,3)}$ Furthermore, a small-scaled indoor runoff test system ${ }^{4)}$ with controlled rainfall conditions was also developed, due to the rarity of field-scale runoff events. However, tests have mainly been performed on fields of Ando soil, which covers more than $40 \%$ of upland fields in Japan. Other kinds of soils may respond differently to field-scale runoff. ${ }^{5}$ )

In this study, runoff events in a field of Gray lowland soil, which covers around 5\% of upland fields in Japan, were observed in the rainy season (from May to July) of 1997. The pesticides in surface flow water and residues in the soil surface layer were analyzed. Water runoff from the field of Gray lowland soil was compared with that in a field of Ando soil in the typhoon season (from September to October) of 1997. Furthermore, the indoor runoff test system with artificial rainfall was used to better understand the runoff on Gray lowland soil.

\section{MATERIALS AND METHODS}

\section{Location and Conditions of Test Fields}

The runoff tests were conducted in two test fields, A and B, located on the Miyazaki Experiment Station of the Japan

\footnotetext{
* To whom correspondence should be addressed. E-mail address: ytakasan @jppa.or.jp
}

Plant Protection Association (JPPA) in Sadohara, Miyazaki Prefecture, Japan. Test field A is composed of Gray lowland soil. Field B was dressed with Ando soil to a thickness of approx. $30 \mathrm{~cm}$ on August 2, 1997. Soil properties are listed in Table 1.

Both fields had an area of $500 \mathrm{~m}^{2}$ (20 m wide and $25 \mathrm{~m}$ long). Field A was sloped to an angle of $1.7^{\circ}$ (A1) in the $1 \mathrm{st}$ experiment which was conducted from May to July, 1997. In field A1, cabbages (cv. Shutoku) were planted on 12 ridges oriented along the slope on May 12. In the 2nd experiment, field A1 was sloped to an angle of $1.15^{\circ}$ (A2) on August 3. In field A2, Japanese radishes (cv. Taibyou-sobutori) were sown on 32 ridges oriented along the slope on October 1. Field B with the surface of Ando soil was also sloped to the same angle as field A2 on August 3 and seeds were sown on October 1. The experiment was conducted from September to November.

Precipitation data were obtained at 10 min intervals by an automatic weather recording system (KADEX-UP, KONA system Co., LTD.)

\section{Pesticides}

In the 1st experiment on field A1, three applications of pesticide (P1-P3) were employed. First, Diazinon granule was applied (P1) with broadcast treatment at a rate of a.i. 300 $\mathrm{g} / 10 \mathrm{a}$ on May 12, just before the planting of cabbages. Then, a mixture of Chlorothalonil (TPN: $400 \mathrm{mg} / \mathrm{l}$ ) and Dimethoate $(430 \mathrm{mg} / 1)$ was sprayed (P2) onto cabbages at a rate of $2391 / 10$ a on June 30 . Finally, eight days after the 2 nd application, a mixture of TPN ( $400 \mathrm{mg} / \mathrm{l})$, Diazinon (400 $\mathrm{mg} / \mathrm{l})$ and Dimethoate $(430 \mathrm{mg} / \mathrm{l})$ was applied (P3) at a rate of $2241 / 10$ a on July 8 .

In the 2 nd experiment on fields $\mathrm{A} 2$ and $\mathrm{B}$, a mixture of TPN, Diazinon and Dimethoate of the same concentration as above was sprayed onto Japanese radishes at a rate of 1941/ 10 a for field $\mathrm{A} 2$ and 178 1/10 a for field B on November 12 .

\section{Sample Collection}

In the 1st experiment, ten liters of surface water was collected using a stainless steel bucket from field Al during runoff after pesticide applications. The bucketful of water was allowed to settle for $10 \mathrm{~min}$. Then, the supernatant (approx. 21) was collected as a water sample. As a soil sample, ten soil cores $(5 \mathrm{~cm}$ in diameter and $5 \mathrm{~cm}$ in depth) were collected at random from test field A1.

In the 2 nd experiment on fields $\mathrm{A} 2$ and $\mathrm{B}$, no runoff event was observed after the 4th pesticide application. Thus, no sample was collected.

\section{Pesticide Analyses}

Pesticide residues in water and soil samples were analyzed by GC-MS as described previously. ${ }^{3)}$ Water samples were 
Table 1 Soil properties of test fields $\mathrm{A}$ and B.

\begin{tabular}{|c|c|c|c|c|c|c|c|c|c|c|}
\hline \multirow[b]{2}{*}{$\begin{array}{l}\text { Test } \\
\text { field }\end{array}$} & \multirow{2}{*}{$\begin{array}{l}\text { Depth } \\
\text { of soil } \\
\text { layer } \\
(\mathrm{cm})\end{array}$} & \multirow[b]{2}{*}{$\begin{array}{l}\text { Soil } \\
\text { texture }\end{array}$} & \multirow[b]{2}{*}{$\underset{\left(\mathrm{H}_{2} \mathrm{O}\right)}{\mathrm{pH}}$} & \multirow[b]{2}{*}{$\begin{array}{c}\mathrm{CEC} \\
(\mathrm{mEq} / 100 \mathrm{~g})\end{array}$} & \multirow[b]{2}{*}{$\mathrm{PAC}^{\mathrm{C})}$} & \multicolumn{3}{|c|}{$\begin{array}{l}\text { Three-phase distribution } \\
\text { (at pF 1.5) }\end{array}$} & \multirow{2}{*}{$\begin{array}{l}\text { Dry } \\
\text { soil } \\
\text { density } \\
\left(\mathrm{g} / \mathrm{cm}^{3}\right)\end{array}$} & \multirow{2}{*}{$\begin{array}{l}\text { Relative } \\
\text { water } \\
\text { permeability }\end{array}$} \\
\hline & & & & & & $\begin{array}{l}\text { Gaseous } \\
\text { phase }\end{array}$ & $\begin{array}{l}\text { Liquid } \\
\text { phase }\end{array}$ & $\begin{array}{l}\text { Solid } \\
\text { phase }\end{array}$ & & \\
\hline \multirow{4}{*}{ A } & $0-22$ & $\mathrm{SL}$ & 5.98 & 17.16 & 890 & 30.5 & 29.7 & 39.8 & 1.04 & High \\
\hline & $22-38$ & L & & & & 10.3 & 38.6 & 51.1 & 1.31 & Medium \\
\hline & $38-42$ & SL & & & & 6.5 & 41.7 & 51.8 & 1.31 & Low \\
\hline & $42-62$ & $\mathrm{CL}$ & & & & & & & & Low \\
\hline \multirow{4}{*}{ B } & $0-23$ & $\mathrm{~L}$ & 5.69 & 28.45 & 2550 & 36.4 & 44.4 & 19.2 & 0.46 & High \\
\hline & $23-32$ & $\mathrm{~L}$ & & & & 18.0 & 56.8 & 25.2 & 0.59 & $\mathrm{High}$ \\
\hline & $32-69$ & $\mathrm{CL}$ & & & & 7.1 & 64.0 & 28.9 & 0.68 & Medium \\
\hline & $69-$ & $\mathrm{S}$ & & & & & & & & $\mathrm{High}$ \\
\hline
\end{tabular}

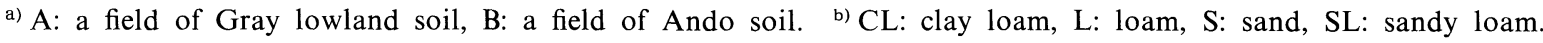

${ }^{c)}$ phosphate absorption coefficient.

separated to aqueous phase and suspended solids (SS) samples, then analyzed separately. ${ }^{3)}$ The detection limits were $0.0005 \mathrm{mg} / 1$ for aqueous phase samples, $0.7-0.1 \mathrm{mg} / \mathrm{kg}$ for SS and $0.01 \mathrm{mg} / \mathrm{kg}$ for soil samples. The recovery of each pesticide was $86-96 \%$ for aqueous phase samples at $0.1 \mathrm{mg} / 1$ and $72-88 \%$ for soil samples at $1.0 \mathrm{mg} / \mathrm{kg}$.

\section{Indoor Runoff Test}

The indoor runoff test system ${ }^{4)}$ was employed for analyzing water runoff on Gray lowland soil. In the tests, $200 \mathrm{ml}$ samples of runoff water were ollected continuously from 0.7 $\mathrm{m}^{2}$ of test plot covered with Gray Lowland soil after 12, and $20 \mathrm{~mm} / \mathrm{hr}$ of rainfall and with Ando soil ${ }^{4)}$ after $30 \mathrm{~mm} / \mathrm{hr}$ of rainfall. Collection times for the samples from each test plot were measured. The Gray lowland soil used has the texture of clay loam (Clay $24.5 \%$, silt $26.7 \%$, sand $48.7 \%$ ): organic carbon $1.69 \%$, pH $5.5 / \mathrm{H}_{2} \mathrm{O}$ and $5.0 / \mathrm{KCl}, \mathrm{CEC} 10.7 \mathrm{mEq} / 100$ $\mathrm{g}$, phosphate absorption coefficient 889 , and maximum water holding capacity $62.0 \%$. The Ando soil used has a texture of clay loam (Clay $17.4 \%$, silt $29.9 \%$, sand $52.7 \%$ ): organic carbon $3.42 \%$, pH $6.1 / \mathrm{H}_{2} \mathrm{O}$ and $5.1 / \mathrm{KCl}$, CEC $25.5 \mathrm{mEq} / 100 \mathrm{~g}$, phosphate absorption coefficient 1120 , and maximum water holding capacity $81.8 \%$.

\section{RESULTS}

\section{Water Runoff from Fields of Gray Lowland Soil and} Ando Soil

The runoff events on test fields A1, A2 and B in 1997 are shown in Fig. 1 and Table 2. Amounts of water were measured using 201 buckets and 1001 and 5001 tanks. In some runoff events, however, the amounts could not be measured due to overflow from the tanks. In series of runoff events within 6 hours caused by chain rainfall, $\left.{ }^{6}\right)$ the events were counted as one runoff. A total of 13 runoff events were observed on test field A1 (Fig. 1) and 4 on field A2 (Table 2). On the other hand, only two runoff events were observed on field B following rainfall simulating a typhoon (Table 2).

\section{Comparison of Gray Lowland and Ando Soils by Indoor Runoff Tests}

In the indoor runoff tests, collection times for $200 \mathrm{ml}$ of runoff water from the test plots of Gray lowland soil and Ando soil are shown in Fig. 2. Runoff from Gray lowland soil at $12 \mathrm{~mm} / \mathrm{hr}$ of rainfall occurred more easily than that

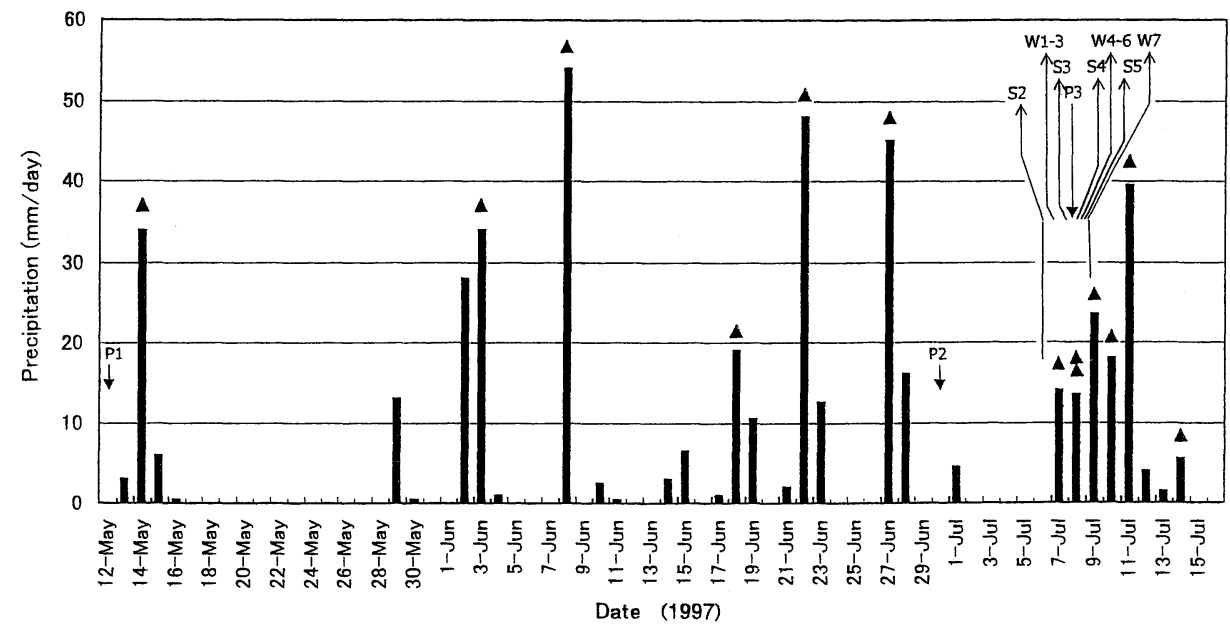

Fig. 1 Precipitation $(\mathrm{mm})$ per day and runoff events (A) from May 12 to July 151997 . Arrows indicate the dates of the 1 st to 3rd pesticide applications (P1-P3), and of soil sample (S2-S5) and water sample (W1-W7) collections, respectively. 
Table 2 Occurrence of water runoff from test fields A2 and B in September and October 1997.

\begin{tabular}{|c|c|c|c|c|c|c|}
\hline \multirow{3}{*}{$\begin{array}{l}\text { Occurrence } \\
\text { of } \\
\text { runoff } \\
\text { events }\end{array}$} & \multirow{3}{*}{$\begin{array}{l}\text { Amount of } \\
\text { precipitation } \\
\text { (mm) }\end{array}$} & \multirow{3}{*}{$\begin{array}{l}\text { Maximum } \\
\text { rainfall } \\
(\mathrm{mm} / \mathrm{hr})\end{array}$} & \multicolumn{4}{|c|}{ Water runoff } \\
\hline & & & \multicolumn{2}{|c|}{ Field A2 } & \multicolumn{2}{|c|}{ Field B } \\
\hline & & & $\begin{array}{c}\text { Amount } \\
(\ell)\end{array}$ & $\begin{array}{c}\text { Ratio } \\
\left(\frac{\circ}{0}\right)\end{array}$ & $\begin{array}{c}\text { Amount } \\
(\ell)\end{array}$ & $\begin{array}{c}\text { Ratio } \\
\left(\frac{\circ}{0}\right)\end{array}$ \\
\hline Sep. $8,3: 10-5: 30$ & 13.5 & 11.5 & 430 & 6.4 & $-{ }^{-b)}$ & \\
\hline Sep. $12,21: 20-22: 40$ & 20.0 & 19.5 & 45 & 0.5 & - & \\
\hline Sep.16,1:00-13:00 & 233.0 & 33.0 & $O F^{a)}$ & $\mathrm{OF}$ & 410 & 0.4 \\
\hline Oct. $2,8: 10-10: 20$ & 21.07 & 11.5 & 1100 & 10.57 & -1 & \\
\hline Oct. $2,11: 30-14: 20$ & 86.5 & 23.0 & $12200\}$ & $50.8\}$ & $1590\} 2330$ & $6.6\} 5.4$ \\
\hline Oct. $2,14: 20-16: 20$ & $17.5^{J}$ & 13.0 & $O F$ & $\mathrm{OF}$ & $740^{\circ}$ & 8.5 \\
\hline
\end{tabular}

a) OF: Amount of runoff was not measured due to overflow from collection tanks. b) No runoff event was observed.

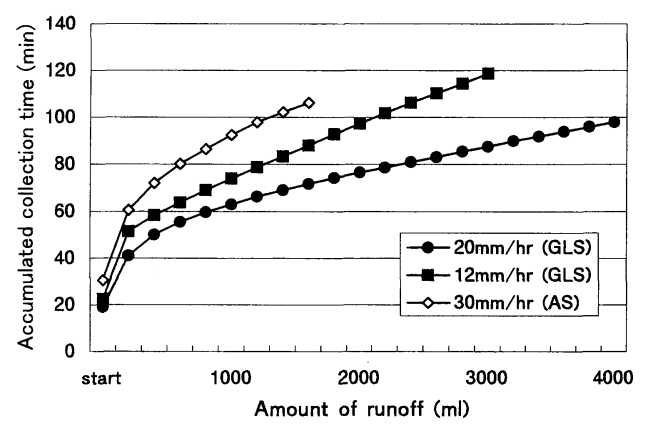

Fig. 2 Accumulated collection time for every $200 \mathrm{ml}$ of runoff water from each test plot $\left(0.7 \mathrm{~m}^{2}\right)$ of Gray lowland soil (GLS) at $12(\mathbf{\square})$ and $20 \mathrm{~mm} / \mathrm{hr}(\mathbf{\bullet})$ of rainfall and Ando soil (AS) at $30 \mathrm{~mm} / \mathrm{hr}(\diamond)$ of rainfall in the indoor runoff test.

from Ando soil at $30 \mathrm{~mm} / \mathrm{hr}$ of rainfall. When the $\mathrm{pF}$ value in Ando soil was around 1.6 (saturated soil moisture), runoff was observed as in a previous report. ${ }^{4)}$ In Gray lowland soil, however, runoff was observed at a pF value of even 2.9. During the runoff tests, soil moisture ( $\mathrm{pF}$ value) at a depth of $15 \mathrm{~cm}$ in the test plots of Gray lowland soil did not change, even though the surface of the test plots was tilled thoroughly before testing.

\section{Pesticide Runoffs and Residue on Gray Lowland Soil}

Seven water samples (W1 to W7) were collected from several runoff events on field A1 (Fig. 1). Sample W1 was collected from 4191 of runoff water. The amount of runoff water relative to precipitation was $9.9 \%$. Samples W2 and W3 were collected from a single event, which induced 581 of runoff water. The percentage of runoff water was $1.2 \%$. Sample W4 was collected just after a runoff event started, W5 at the middle and W6 just before the end. In this event, the amount and extent of runoff was 14401 and $36.0 \%$. Furthermore, sample W7 was collected early (72.51) in a runoff event, which finally produced 36031 of water runoff. The percent runoff was $39.0 \%$. The pesticide concentrations in the water samples are shown in Table 3.

Five soil samples (S1 to S5) were also collected from field A1 just before and after the pesticide applications and after the runoff events (Fig. 1). Pesticide residues in soil are also shown in Table 3. Although $345 \mathrm{~mm}$ of precipitation and 7 runoff events were observed from the 1st application to the collection S2 (55 days), approx. 1\% of the Diazinon applied was still detected in the soil (S2). Although three water samples (W1, W2 and W3) were taken between S2 and S3, the concentrations of Diazinon in the samples were below the detection limit. No TPN was detected from the soil (S2) 6 days after the 2 nd application though only $4.5 \mathrm{~mm}$ of rainfall and no runoff were observed during the 6 days. However, very little TPN was detected in the water samples $\mathrm{W} 1$ to $\mathrm{W} 3$ between 6 and 8 days after the 2 nd application.

\section{DISCUSSION}

In previous studies, ${ }^{2,3)}$ little water runoff had been observed on fields of Ando soil in Ushiku, Ibaraki. However, water runoff on Gray lowland soil seemed to occur quite frequently. In the present study, the relative water permeability was high in the plowed layer of field $\mathrm{A}$, but low at deeper layers. Thus, rainwater may have difficulty percolating downward through Gray lowland soil. On the other hand, in field B with Ando soil, the relative water permeability was high through deeper soil layers (Table 1). Based on the soil properties of the fields, field A (Gray lowland soil) seemed to more easily induce water runoff than field B (Ando soil). This was supported by the results of the indoor runoff tests (Fig. 2).

As the slope of field A2 was gentler than that of field A1, a higher intensity of rainfall would be required for runoff to occur. Moreover, more intensive rainfall would be required in field $\mathrm{B}$ than field $\mathrm{A} 2$. When the average intensity of rainfall was more than $5 \mathrm{~mm} / \mathrm{hr}$ in field $\mathrm{Al}$, over $10 \mathrm{~mm} / \mathrm{hr}$ in field A2 and more than $20 \mathrm{~mm} / \mathrm{hr}$ in field $\mathrm{B}$, runoff was induced. Based on a previous study, ${ }^{4}$ the occurrence of runoff on fields of Ando soil required not only intense (around over $20 \mathrm{~mm} / \mathrm{hr}$ ) rainfall but also more than 30-60 $\mathrm{mm}$ of precipitation before the occurrence. This is one reason why water runoff did not occur in field B at $19.5 \mathrm{~mm} / \mathrm{hr}$ of rainfall on September 12 (Table 2).

In many studies ${ }^{7,8)}$ and our previous studies, ${ }^{2-4)}$ pesticide runoff reached a maximum when rainfall occurred immediately and intensely after pesticide application. In the present study, the concentration of runoff pesticides was also higher 
Table 3 Days after pesticide applications and pesticide concentrations in the collected samples.

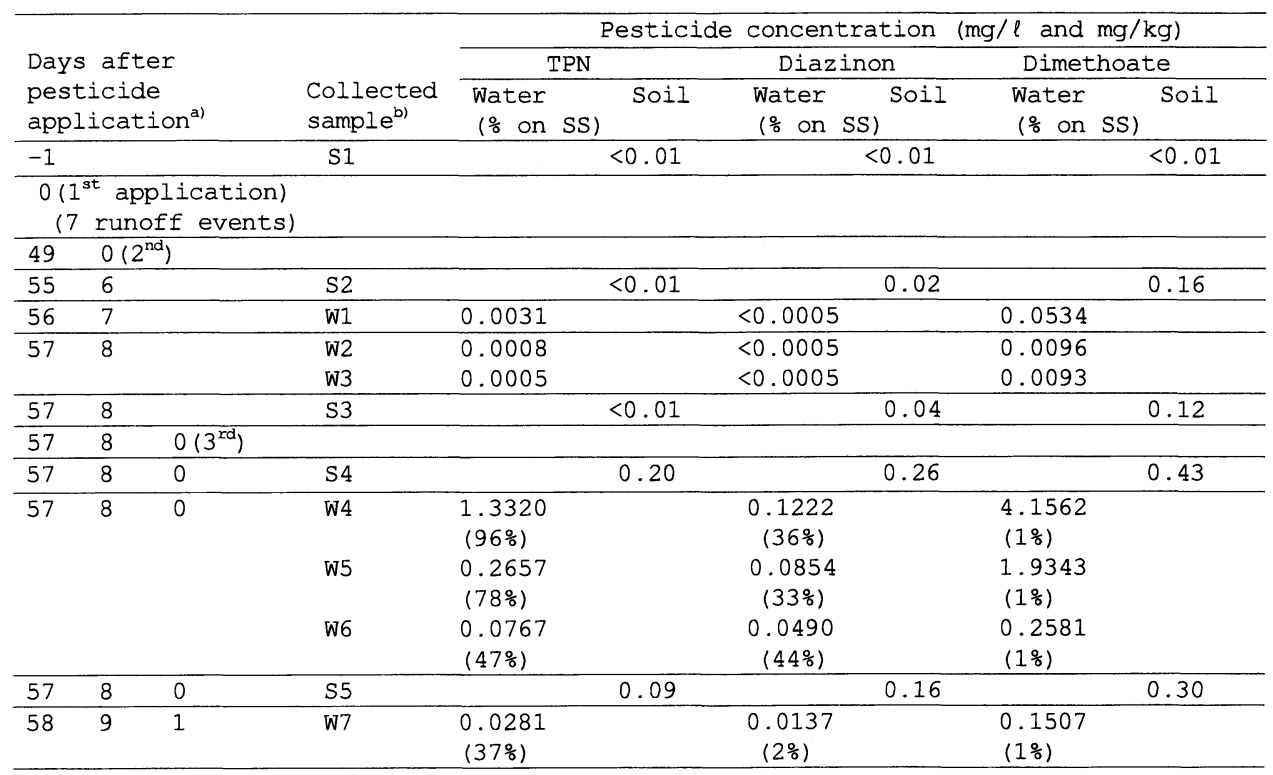

a) 1st application: Diazinon granular, 2nd: mixture of TPN and Dimethoate, 3rd: mixture of TPN, Diazinon and Dimethoate. b) S1 to S5: soil samples, W1 to W7: water samples. Pesticide concentrations of runoff water include the residues on SS.

in W4 than W1. Among three pesticides, TPN mainly ran off with fine soil particles (SS), though the percentage of TPN in SS decreased from $96 \%$ (W4) to $47 \%$ (W6). TPN concentrations in the aqueous phase of $\mathrm{W} 4$, W5 and W6 without SS were only but constantly around $0.05 \mathrm{mg} / 1$. On the other hand, the percentages of the other two pesticides in SS were 33-44\% (Diazinon) and 1\% (Dimethoate) (Table 3).

Pesticide concentrations in S5 indicate that approx. 55\% of TPN, 38\% of Diazinon and 30\% of Dimethoate seemed to be lost from the soil surface layer (S4) in a single runoff event. As over $70-90 \%$ of pesticides in Ando soil were lost in the previous study, ${ }^{2)}$ the extent to which pesticide dissipates from the surface layer is smaller for Gray lowland soil than Ando soil. The result suggests that the pesticides on Gray lowland soil are mainly removed horizontally by rainfall, while those on Ando soil are removed not only horizontally but also vertically. In a previous study on Ando soil (Ushiku), ${ }^{2)}$ the order of pesticide dissipation from the surface layer after a runoff event was Dimethoate $>$ TPN $>$ Diazinon. The order corresponded with that of half-life in the field. ${ }^{9)}$ However, in this experiment on Gray lowland soil, it was TPN $>$ Diazinon $>$ Dimethoate. This characteristic of runoff would be induced by the properties of the soil and/or climatic conditions although more tests are required to make a conclusion.

\section{ACKNOWLEDGMENTS}

The greater part of this research was supported by the Soil and Pesticide Division, Water Quality Bureau, Environment Agency of Japan (Presently: Ministry of the Environment of Japan), though this paper does not contain any opinions of the Ministry.
The authors are indebted to Mr. Akitoshi Yokoyama, Miyazaki Agricultural Experiment Station of Miyazaki Prefecture, for analysis of soil properties of the test fields.

\section{REFERENCES}

1) R. A. Leonard: "Pesticides in the Soil Environment: Processes, Impacts \& Modeling," ed. by H. H. Cheng, SSSA Book Series No. 2, Soil Science Society America, Madison, pp. 303-349, 1990.

2) Y. Takahashi, Y. Odanaka, Y. Wada, Y. Minakawa and T. Fujita: J. Pesticide Sci. 24, 255-261 (1999).

3) Y. Takahashi, Y. Wada, Y. Odanaka and H. Furuno: $J$. Pesticide Sci. 25, 140-143 (2000).

4) Y. Takahashi, Y. Wada, Y. Odanaka, Y. Kakuta and T. Fujita: J. Pesticide Sci. 25, 217-222 (2000).

5) Crop Production Division, Agricultural Production Bureau, Ministry of Agriculture, Forestry and Fisheries: Chiryoku-hozen-taisaku shiryo (Countermeasure of maintenance of soil fertility), No. 55, pp. 1-14, 1979 (in Japanese).

6) W. H. Wischmeier and D. D. Smith: "Predicting Rainfall Erosion Losses - a Guide to Conservation Planning," U. S. Department of Agriculture, Agriculture Handbook No. 537, pp. 5-8, 1978.

7) J. D. Grynor, D. C. MacTrisk and W. I. Findlay: Arch. Environ. Contam. Toxicol. 23, 240-245 (1992).

8) B. T. Bowman, G. T. Wall and D. J. King: Can. J. Soil Sci. 74, 59-66 (1994).

9) A. G. Hornsby, R. Don Wauchope and A. E. Herner: "Pesticide Properties in The Environment," Springer-Verlag New York, Inc., New York, p. 68, pp. 83-84 and p. 92, 1996. 
要

約

\section{畑地戋場における自然降雨による農薬の地表流出}

高橋義行，高田正司，小田中芳次，井園佳文 長岡広行, 沼田京太，藤田俊一

宮崎県佐土原町の圃場において，キャベツを定植した灰色低 地土の緩斜面圃場（A1: $1.7^{\circ}, 5$ a) で1997 年 5 7 月の梅雨期に 地表水の流出が計 13 回観察された.この圃場にダイアジノン粒 剂の定植時処理 (a.i. $300 \mathrm{~g} / 10 \mathrm{a})$ ，その 55 日後に TPN (400 mg/ 1) とジメトエート $(430 \mathrm{mg} / \mathrm{l})$ の混用液 $(239 \mathrm{l} / 10 \mathrm{a})$ ，その 8 日 後に TPN, ダイアジノン $(400 \mathrm{mg} / \mathrm{l})$ とジメトエートの混用液 (224 1/10 a) を散布した。表流水によって流出した TPN の 96\% (流出直後) から $47 \%$ (終了直前) は, 浮遊物質 (SS) とともに
流出した. 一方，ダイアジノンとジメトエートはそれぞれ 33〜 $44 \%$ よび $1 \%$ ほぼ一定の割合で SS とともに流出した.また， 同年 9〜10月の台風時期には $\mathrm{A} 1$ 圑場の傾斜を $1.15^{\circ}$ に調整し た圃場（A2）と黒ボク土の圃場（B, $5 \mathrm{a}$,傾斜 $1.15^{\circ}$ ) にダイコン を播種して地表水の流出頻度を比較した。 その結果，灰色低地 土では 4 回, 黒ボク土では台風時の降雨によって 2 回の地表流 出が認められた。灰色低地土の A1 固場では平均降雨強度 5 $\mathrm{mm} / \mathrm{hr}$ 前後以上で, $\mathrm{A} 2$ 圑場では $10 \mathrm{~mm} / \mathrm{hr}$ 以上の降雨によっ て，また黒ボク土の B 圃場では $20 \mathrm{~mm} / \mathrm{hr}$ 以上の降雨によって 地表水の流出が生じた。 さらに，人工降雨装置を用いた屋内小 規模地表流出試験系でも灰色低地土からは黒ボク土よりも容易 に表流水が発生した。 